\title{
The Implementation Effort Islamic Law Norms in Activities for Overcoming Pornography and Pornoaction on Mass Media
}

\author{
Ramlani Lina Sinaulan 1 \\ ${ }_{1}^{1}$ Postgraduate Program Jayabaya University, Jakarta, Indonesia \\ Email: linasinaulan@gmail.com
}

\begin{abstract}
:
This paper discusses the effort Islamic Law norms in activities for overcoming pornography and porno-action on mass media. By using normative legal research, the result found that the concept of Islamic law, behave based on sharia, shows the importance of shaping the personality traits of Islam (syakhsiyya Islämiyya) and based on the devotion and faith. Because of the relation to the formulation of the rule of law against pornography behavior, it can not be designed, prepared and formulated based on social values. Based on the facts of society, as a result of the moral decadence that led to a permissive attitude towards their cultural infiltration, the social values in assessing the behavior may become more permissive toward behavior. However, the use of religious norms which have universal properties will not change, and even capable of elastic with the times.
\end{abstract}

Keywords: Pornography, Pornoaction, Islamic Law, Tabarruj.

\section{A. INTRODUCTION}

The Industrial development of information media on this era is very fast and rapidly grow ( $\mathrm{He} \mathrm{\&} \mathrm{He}$, 2015). Even impressed is not controlled properly and seriously by law enforcement. The mass media such as printed and electronic was most widely used by the public in various social strata, especially in the urban community. Therefore, the mass media is often used as a tool of transform information from two directions, from the mass media towards the society or among the community itself (He \& He, 2015).

The improve of competitiveness on mass media, it is not rare that mass media using news or pictures like a erotica and/or porn as the appeal of the media. News erotica or porn in question are news for articles, pictures or movies that contain meaning erotica or porn. Rampant of emerging mass media, especially print media is a manifestation from the freedom of expression that was hailed by all parties. But in fact, in line with the rapid growth of the print and electronic mediasso that freedom of expression is precisely degraded or decrease in social control by the government and by the community itself, which causes structural moral decadence.

One of the most prevalent and growing in the mass media at this time is the rise of things nuanced porn. Pornography and pornoaction always hiding behind the democracy and freedom, also the emergence of notion that it is the desire and demand of society and regard it as an art.

Based on the research results, worldwide there are about 26,000 porn sites. This amount is expected to grow by 1,500 new porn sites every month. Local porn sites alone no less than 1100 
pieces. Likewise, with books, pictures and pornographic VCDs it is not difficult to find (Andaryuni, 2012).

However its become ironic when the justice system in Indonesia either its legislations and law enforcement is like not having clear limits on what it meant by pornography and pornoaction itself. So that was a heated debate in the community and confusion in mindset regarding what constitutes pornography and pornoaction.

In the chapter on crimes against decency in WvS derived from the Dutch language title: "misdrijven tegen de zeden". According Mardjono Reksodiputro, the definition of "zeden" does not always have to be related to sexual life. Can be interpreted anyway morals, manners, politeness and because it is also related to "public morals" or "morals" (crimes against public morals) (Reksodiputro, 2006).

Sexual life is the core of prohibited act in this chapter originally was aimed only at "bodily and psychological integirty" and therefore regulate the criminal act of rape, abortion, sexual immorality, incest (sex with family members by blood relative), prostitution and adultery that tangent to the sexual life is pornography (writing, pictures or objects, and sing and pronounce speech in violation of decency) (Cf., Graham, 2012 \& UNFPA, 2014).

Concerns about the change in people's attitudes, so emergence the MPR Decree No.VI/2001 specifically regulates the ethics of nation and also there is MPR Decree No.VI/2002 that specifically commanded that government to immediately establish Pornography Act, "according Gati Gayatri as team leader for designing Draft Law on Pornography, and also an expert of Communication Studies from University of Indonesia (hukumonline.com, 2003).

During this time the realm of arts refuse that not all elements of 'nudity' can be called pornography as part of a destructive element. Though already a lot of research on the social impact of pornography and cases that have occurred based on pornography. It is based on research conducted by A. Hamzah (1987) about the dangers of pornography especially among the youth (Ybarra \& Mitchell, 2005), which is said to be that of an interview with the case, obtained information that pornographic films, readings pornographic, images and others have contribution to big enough for the occurrence of sexual intercourse, but without sufficient knowledge about the process of pregnancy, prevention and so on (Cf., Owens, Behun, Manning \& Reid, 2012).

Why during periods of few tens of years peoples experience changes of sustaining the norms in the community itself? According Soerjono Soekamto (1997) that social changes in society can result from a variety of causes. The causes may come from the community itself (internal) or from outside the community (external). As the internal causes, among others, can be mentioned for example the growth of population; new discoveries; contention (conflict); or perhaps because of occurrence a revolution. External causes may include the causes that originated from the physical natural environment, the influence of other cultures, wars and so on. A change can happen quickly when a society more frequent the occurence communications contact with other society, or already have an advanced education system (Soekamto, 1997). Due to the presence of changes in social norms in the society so that the provisions contained in the legislation by linking social norms as an indication of a violation of law has been unable to snare the perpetrators of criminal act of pornography (Gerke, 2012).

The word of pornography based on dictionary Indonesian has meant reading irreverent. The definition given by the dictionary Indonesian heavily dependent on a sense of propriety itself was developed in the community. Can the author describing here one example from change of courtesy 
that developed in the community. Namely his free a girl with a boy were flirting and making out in public who at the past generation its very taboo and disrespectful.

According to the Dictionary of Law, M.A. Tair \& H. van der Tas (1972), pornography is exposing and promulgate pictures of obscenity in public to excite lust. Meanwhile, according to other legal experts, A. Hamzah (1987) claimed that of pornography is derived from two words of origin, namely porn and graphic. Porn comes from the Greek "porne" means prostitute, whereas graphy comes from the word "Graphien" which means the expression (expression). Thereby, pornography literally means an expression about a courtesan, so it can be interpreted that pornography is:

1. An expression in the form of stories about prostitutes or prostitution;

2. A disclosures in written form or painting about erotic life, with the aim to cause sexual stimulation to its readers or view it (Hamzah, 1987).

On August 22, 2001 the Indonesian Ulema Council issued Decree Fatwa by the Fatwa Committee No. 287 of 2001 on Pornography and Porno action where the contents stated that describe directly or indirectly erotic behavior, either by painting, drawing, writing, sound, billboards, advertisements, and speech; both through print and electronic media, letting the nakedness of an open or strict dress or translucent with a view to be photographed, whether to be printed or visualized and taking pictures, sexual intercourse or a sexual scene in front of people, shooting sexual intercourse or sexual scenes either to oneself or others and look at sexual intercourse or sexual scenes, reproduce, distribute, sell, and buy and see or pay attention to pictures of people, either print or visual open his private parts or tight or see-through dress that can arouse lust, or images of sexual intercourse or sexual scenes, do intimate, alone together (khalwa) among men with women who are not mahram, and deeds and other similar approaches or encourage sexual relations outside marriage, exposing the nakedness of the body between the navel and knees for men as well as all parts of the female body except the face, palms and soles of the feet, except in matters justified in shar'i, wear invisibility dress or tight to show body contour, perform an act or a remark that could encourage sexual intercourse outside of marriage, helping with any forms or letting without denial actions that are forbidden, earn money benefits, and or facilities self acts prohibited above is unlawful (Djubaedah, 2003).

Then in one after another with a call (tawșiya) issued by the Executive Board Indonesian Ulema Council, dated February 19, 2002, which among other things it condemned the multiple viewing/playback of movies and porn news on several television stations. And also requested the Government to curb the screening (Djubaedah, 2003).

Meanwhile, according to Article 1 paragraph 1 of Law No. 44 of 2008 concerning Pornography asserts "Pornography is drawings, sketches, illustrations, photographs, text, voice, sound, moving pictures, animation, cartoons, conversation, gestures, or forms other messages through various forms of communication media and / or performing in public, which contains obscenity or exploitation sexually violate moral norms in society."

Such arrangements have differences with the previous arrangements in the Criminal Code. Pornography in the Criminal Code regulated in Book II, Chapter XIV of the Criminal Decency Article 281-282 and Book III Chapter VI about Breach Decency Article 532-533, both only contain norms that should not be violated and contains sanctions. whereas the article 281 and 282 is a crime, while in article 533 is an offense. In Article 282 intends to protect the social norms in general, whereas Article 533 to protect the interests of young children who are minors. That prohibited is "on where the destined for public traffic, showing .... something that could lead to lust young kids". 
Based on provisions, the apparent difference between the definitions of disclosed by the Indonesian Ulema Council with the positive legal norms contained in Law No. 44/2008 as well as the Criminal Code. Although the definition in Article 1 paragraph 1 of Law No. 44/2008 is closer to the definitions of the Indonesian Ulama Council, but the fulfillment of the elements in Article 1 paragraph 1 of Law No. 44/2008 it was highly dependent with a valuation.

Based on the foregoing, the authors formulate the research problem as follows:

"How does the concept of Islamic law in assessing the behavior of pornography as an act that is forbidden?"

\section{B. METHODS}

This study is a normative legal research, the research to obtain the necessary data with respect to the problem. The study used secondary data consists of primary legal materials, secondary law and tertiary legal materials. In addition, it also used primary data such as interviews as supporting secondary data. To analyze the juridical analysis was conducted using qualitative method.

\section{RESULT AND DISCUSSIONS}

Islamic law in its use for the development of national law can be justified is philosophically, constitutional, nor from terms of the general policy of country's development. Philosophically, the first precepts Belief in God Almighty is a strong basis for the religious law into national law (Arifin, 2010). Constitutionally, it is emphasized that the Republic of Indonesia based on belief in almighty God; and the policy of the state, the religious law for formation of national law contained in archipelago insight (Aripin \& Salim, 2001 \& Andaryuni, 2012).

In principle, the implementation of Islamic Criminal Law in dealing with pornography lies fully on Government / State Islam. Due to absence of governance then instead an obligation to implement the Islamic Criminal Law, however look at the word of Allah in the Qur'an Surah Ali Imran verse 110 which reads as follows:

"You are the best nation produced [as an example] for mankind. You enjoin what is right and forbid what is wrong and believe in Allah. If only the People of the Scripture had believed, it would have been better for them. Among them are believers, but most of them are defiantly disobedient."

Q.S. Al Maidah verse 44 :

"... And whoever does not judge by what Allah has revealed - then it is those who are the disbelievers."

Q.S. Al Maidah verse 45 :

"... And whoever does not judge by what Allah has revealed - then it is those who are the wrongdoers alone together"

Q.S. Al Maidah verse 47 :

"... And whoever does not judge by what Allah has revealed - then it is those who are the defiantly disobedient." 
And Q.S. Al Maidah verse 50 :

"Then is it the judgement of [the time of] ignorance they desire? But who is better than Allah in judgement for a people who are certain [in faith]."

So according to author, based on the verse so Moslems should encouraged and obligated to impart truth that comes from God and His Messenger, including convey the laws of God. Likewise, when we perceive the problem of pornography and sexually explicit, as expressly the Islamic Criminal Law must entered as positive law in Indonesia, but at least we can apply its principles into positive law in Indonesia (Lanlua, 2015).

So it needs a comparison on the concepts of Islamic law with the Indonesian Penal Code relating to the dissemination of pornography within the scope of mass media. In Islamic law, pornography is something which is forbidden because of its tendency leads to adultery. and the jurisprudents have established the rules of fiqh that is, "Everything that delivers to the haram is haram". In jinaayat figh or Islamic criminal law there is no definition of pornography stated explicitly but rather that there are limits to human behavior listed expressly so closing the possibility of pornography (Qaradhawi, 2000).

As pronouncement by Allah in the Qur'an Surah Al-Nur verses 30-31, which reads as follows:"Tell the believing men to reduce [some] of their vision and guard their private parts. That is purer for them. Indeed, Allah is Acquainted with what they do. And tell the believing women to reduce [some] of their vision and guard their private parts and not expose their adornment except that which [necessarily] appears thereof and to wrap [a portion of] their headcovers over their chests and not expose their adornment except to their husbands, their fathers, their husbands' fathers, their sons, their husbands' sons, their brothers, their brothers' sons, their sisters' sons,......."

And also Q.S Al Ahzab verse 59 which reads as follows: "O Prophet, tell your wives and your daughters and the women of the believers to bring down over themselves [part] of their outer garments. That is more suitable that they will be known and not be abused. And ever is Allah Forgiving and Merciful."

Yusuf Al-Qaradawi (2000) explained that for the male aurat are between the navel and the knee, while for women is the entire body except the face and palms. This was confirmed by the word of the Prophet as follows: "From 'Aisha r.a. that Asma' bint Abu Bakr entered the house of the Prophet wearing thin clothing; then the Prophet turned away from him and said, 'O Asma'! A woman when it comes to menstrual age (adult), it could not be seen from her except this and this. He showed the face and his hands" (HR. Abu Daud, Kitab al-Libas, chapter fi ma tubdi al-mar'ah min zinatiha, number 3580.)

Islam abolish all equipment, facilities and things that cause men are inflame to commit criminal acts of adultery that is one of them is pornography. Therefore, Islam ordered women to leave the house when going out on an errand then she should cover their whole bodies with the hijab (Al-Maududi, 1995).

Issues of fashion or trend of dressing is the most crucial element in pornography. In today's fashion world is very close to pornography, which is then stimulated by the mass media, both print and electronic in society cause some people to follow it. Islam has clear boundaries regarding the dress code is good and right under Islamic law.It is said that women should not display their beauty (tabarruj) if she holds firmly ethics as follows (Qaradhawi, 2000): 
1. Lower her gaze. The most valuable jewelry in women is a shame, and an indication of shame is the most prominent lower her gaze.

2. Not to intermingle (ikhtilāt) with men, making it easy to contact and intersect.

3. The clothes according to of Islamic ethics which is syar'i. As for the clothes that syar'i is clothing that meets the following criteria:

a. Cover the whole body, besides those excluded from Al Quran in his words, "that looked away from him." The opinion of the most powerful (räjịh) in this case is the face and both hands.

b. Not transparent and illustrates what is behind the shirt.

c. Not tight and doesn't accentuate the parts interestingly, though not thin or transparent.

d. Not special clothing for men, such as today's trousers. That has been cursed by the Prophet.

e. Not like clothing of disbelievers, whether it Jewish, Christian, and the other polytheists.

4. Remain the maintain authority when walking and speaking, avoiding behavior and body movement also makeup the face that tempting. Allah swt says in the Qur'an Surah Al Ahzab, verse 32: "... then do not be soft in speech [to men], lest he in whose heart is disease should covet, but speak with appropriate speech.".

5. Unintentionally attract male attention to jewelry hidden with a fragrant smell. The Qur'an prohibits because the imagination of men who have high sexual inclination.As in the word of the Prophet: "Any woman who uses perfume and then passes in front of the people so that they smell it, she is a adulterer woman." (Abu Daud, Turmudzi)

Then obviously, that Islam so strict in maintaining human dignity in the world, without having to rely on ethics of courtesy and decency at an era in the community or not depends on the final outcome of an image or visualized.How precisely the expression by Sheikh Muhammad Al-Ghazali, "If we have agreed that TBC is a disease, surely we will not quarrel about the causes of transmission. Similarly, if we have agreed that adultery is a heinous act, we certainly will not be at odds on the prevention of all forms show off the aurat (tabarruj) and propaganda to him which would cause the adultery (Shidqy, 1994).

Moving on from the above description, an assessment of fulfillment the elements from the behavior of pornography, in the context of Islamic law that moved from the restrictions of behavior, and not on the values of social reinforcement. Therefore, in principle, any pornography is a form of behavior that was wrapped with an attitude of disregard for the things that are appropriate and feasible in a community. Where concurrent distortion such meaning from the what something is worth or not worth, with the strengthening of permissive attitude that caused the war of ideas (ghazw al-fikr) through the infiltration of foreign culture.

In the context of Islamic law, how people behave is not based on the its assessment of a social norm, but based on the attitude of monotheism. According Juhaya S. Praja, in Zein (2005), the principles of monotheism is the first step needs to put forward which then juxtaposed with the principle of Amr Ma'rūf Nahy Munkar (Zein, 2005).

According to Ibn Qayyim Al Jauziyah, that phrase of unity when witnessed by those who believe by knowing the understanding and intrinsically, that both rejection (reject God but Allah) and determination (a God is just Allah) which held with heart, oral, and limbs, then this sentences can lift a people's charitable deeds that testifies (Ibnu Qayyim, 2000). 
That became problems is lies in the system proselytizing that partial impressed to Muslims themselves. And a lack of understanding about fiqh proselytizing with better for preachers and scholars, particularly in Indonesia. In conveying intent and the will of Islamic legal system can not only use the approach of figh only, but also have to go through proselytizing approach figh. Then do not be surprised if the people of Indonesia were the majority of Muslims rejected the concept of Islamic law.

Forms is displayed against Islamic law only of punishment solely that always associated with stoning, flogging and the death penalty. But never be disclosed in a straightforward and transparent about the wisdom behind the criminal prosecution. The emergence of such behavior that sometimes can not be blamed for their efforts trying to build the Islamic legal order only through information an outward of verses Al Quran. Thus, the laws of Qur'an always deemed inhumane, and contrary to the very traditional and cultural life of modern man.

Qur'an as a book of guidance for all human beings, the Qur'an certainly contain the principle of law in accordance with the growth and cultural development of society itself. The existence of the principle established by the Qur'an indicates that not all imposible that occur can be absorbed through statements verses. That's the redactional Qur'an only speak in a universal philosophical level. These principles are intended to cover all imposible at the level of meaning (maknawiyah) is not at level of outward forms. Through this level of meaning, the legal principles contained in the Quran can be juxtaposed with the principles of modern secular law (Zein, 2005). Therefore, the prohibition in the form an attitude determination led to values that are universal. The prohibition against revealing the beauty (tabbaruj) is not crystallized from the values which then intangibles to a parameter behaves, but quite the contrary.

One of the reasons philosophically are built in legal argument is that the relationship deed pornography with the owner of body the perpetrators, certainly not out of principle of ownership the body itself for each owner the body, usually always associated with the acquisition of a number of property in return for the owners body concerned.According to Islam, the human body is a mandate from God for owners concerned bodies that must be maintained and kept free of all misconduct, act which reprehensible be detrimental to the owner of body itself,, and the community for the safety of life and living, both in this world and in the hereafter later. Body as a mandate from Allah among other things regulated in Surah an-Nur verse 30 and verse 31, which regulates dressmaking and intercommunication within the family and society for men and women (Andaryuni, 2016).

Behavior revealing the beauty (tabbaruj), often identified with how a woman behaves, but in fact a revealing the beauty (tabbaruj) also binds on men. Where the male genitalia, in Islam also be clearly defined, that is from the navel to the knees. Therefore, if there is a man who shows his limbs from the navel to the knees then he is on violates of Islamic law.In a hadith narrated by Ahmad stated: "Indeed, what is below the navel to the knees of men is his private parts".

In the context of Islamic Criminal Law, of course, very different from the Criminal Law in Indonesia. If we compare with the authority to interpret the law in the context of Islamic law (figh). In the fiqh that someone could give a fatwa, or legal opinion should be mastered and have some kind of scientific support besides also their obligation to be memorizer (hâfiż) from two main sources of law in Islam, namely the Quran and al-Hadith.While in the version of all Indonesia's, has never found a lawyer who is able to memorize a source of criminal law, such as the Penal Code, in properly and well to able to memorize article by article. Whether it's an academic and a practitioner, level of memorizing the contents of article by article from the Penal Code more based on the degree of interaction on those chapters. That is why the science of law is not a science that can be memorized, 
but to be understood. So naturally, when you define the purpose from the criminal law was ultimately never find an agreement or unity meaning. Unlike the Islamic Criminal Law (fiqh al-jināya), that all the scholars had a deal that stipulated in the maqāșid al-sharīa.

As for the meaning of maqāșid al-sharī'a is the intent and purpose of sharia (Allah swt.) which lowers His Sharia in general to humans. In some books of real jurisprudence, for the same purpose, to use a somewhat different meaning, namely al-maqșad al-'ām min al-tashrī', as used by Abd al-Wahhab Khallaf, and maqāṣid al-aḥkām, as used Muhammad Abū Zahrah. According to al-Shāțibī, Allah revealed the Sharia (law) to take the benefit and avoid harm (Ahmad, 2011). Subject of benefit that is agreed in all law covered in five terms, as calculated and referred to by the scholars as al-kulliyyāt al-khams (five main things) which they regard as basics and general purpose of Sharia that must be maintained, as said Imam Al-Ghazalī and Imam al-Shāțibī, namely (Jauhar, 2009):

1. Keeping the religion (hifzz al-dīn); reason ('illat) compulsory fought and go for jihād, if is intended for the enemy or similar purposes;

2. Keeping the the soul (hifz al-nafs); reason ('illat) compulsory Qisas laws, among others by keeping the glory and freedom;

3. Keeping the mind (hifz al-'aql); reason ('illat) prohibition of all the objects intoxicating or narcotics and its kind;

4. Keeping the possessions (hifzz al-māl); reason ('illat) cutting off the hands of thieves, Prohibition of usury and bribery, or take someone else's property by another false way;

5. Keeping descent (hifz al-nasl); reason ('illat) Prohibition of adultery and accuses others fornication (qadhf).

If we look at the purpose of law in general with the aim of the law is based on fiqh al-jināya seen a very noticeable difference. The purpose of law in general, according Wirjono Prodjodikoro that holding the safety, happiness and order in the society. While in the maqāșid al-sharīa on fiqh aljināya has been classified as expressly provided in five main things mentioned above, with the aim of enforcing the law of Allah on earth.

Interesting to observed the views of Topo Santoso, who explains that Sharia maqasid constitutes one of objectives of Islamic law. Still there are two (2) purposes, namely (Santoso, 2001):

1. Guarantee the necessities of life or secondary necessity (hajiyya); and

2. Make the improvements, which makes things can adorn social life and make man capable of act and affairs of better life (tahșilla).

Meanwhile, Zainuddin Ali explained in a more general form, which is associated with the goal of Islamic law is the benefit of human life both physical and spiritual, individual and community. The benefit of is based on the agreement of scholars that maintain religion, life, mind, lineage and property. So the purpose of Islamic law can be viewed from two aspects, namely: (1). Aspects of Islamic law maker is Allah and the Prophet Muhammad; (2). Aspects of being human as actors and implementing Islamic law. Thus, Islamic law to protect the interests of human life in the form of primary (darūriyya), secondary (hajiyya) or tertiary (tahsinniyya/luxuries). Thus, it was concluded that the purpose of criminal law is Islam nourishes the soul, mind, wealth of society in general and descent (Ali, 2012). 


\section{CONCLUSION}

Based on these descriptions, then can drawn some a conclusion that the concept of Islamic law, the Shari'a-based behaves shows how the importance of shaping the personality traits of Islam (syakhsiyya Islāmiyya) and based on the piety and faith. Therefore, in relation to the formulation of legal norms against pornography behavior can not be designed, prepared and formulated based on social values.

Based on the fact of sociological, as a result of the moral decadence that led to a permissive attitude towards their cultural infiltration, the social values in assessing the behavior may become more permissive toward behavior. However, the use of religious norms which have universal properties will not change, and even capable of elastic with development of the era. 


\section{References}

Act No. 44 of 2008 on Pornography.

Ahmad, Agustan. (2011). "Maqasid Al-Syari'ah Al-Syatibi Dan Aktualisasinya Dalam Nilai-Nilai Falsafah Pancasila Hunafa". Jurnal Studia Islamika, Vol. 8 (2).

Al-Maududi, Abu al-A'la. (1995). Kejamkah Hukum Islam (Indonesian edition), Jakarta, Gema Insani Press.

Al-Qaradhawi, Yusuf. (2000). Halal Haram Dalam Islam, (Indonesian edition), Jakarta, Era Intermedia.

Ali, Zainuddin. (2012). Hukum Pidana Islam, Jakarta, Sinar Grafika.

Andaryuni, Lilik. (2012). "UU Pornografi dalam Perspektif Hukum Islam”. Mazahib, Juni 2012. Volume 10, Nomor 1, pp. 26-35, http://dx.doi.org/10.21093/mj.v10i1.107

Arifin, Syamsul. (2010). "Attitudes to Human Rlghts and Freedom of Religion or Belief in Indonesia", Yogyakarta: Kanisius.

Aripin, Jaenal dan Salim, M. Arskal ed., (2001). Pidana Islam di Indonesia. Peluang, Prospek dan Tantangan, Jakarta, Pustaka Fidaus.

Djubaedah, Neng. (2003). Pornografi \& Pornoaksi Ditinjau Dari Hukum Islam, Bogor, Prenada Media.

Gercke, Marco. (2012). Understanding cybercrime: phenomena, challenges and legal response, The ITU Publication.

Graham, Ann - Marie. (2012). Unmarried Mothers: the Legislative Context in Ireland, 1921 - 79. Thesis for the Degree of M.LITT. Department Of History National University of Ireland, Maynooth.

Hamzah, A. (1987). Pornografi Dalam Hukum Pidana: Suatu Studi Perbandingan, Jakarta: Bina Mulia.

He, L. and He, J., (2015). "The Revolution of Communication Media and Its Impact on Education". Journal of Social Sciences, 3, pp. 123-127. http://dx.doi.org/10.4236/jss.2015.38014

https://hukumonline.com "Suara dan Gerakan Merangsang Nafsu Seksual Dianggap Pornografi", accessed, 15 February 2003.

Ibnu Qayyim, Al Jauziyah. (2000). Panduan Hukum Islam, (Indonesian edition), Jakarta, Pustaka Azzam.

Jauhar, Ahmad Al-Mursi Husain. (2009). Maqashid Sharia, Jakarta: AMZAH.

Kitab Undang-undang Hukum Pidana (KUHP). 
Mardjono Reksodiputro. (2006). "Arah Hukum Pidana dalam Konsep RUU KUHPidana dalam Beberapa Tulisan Terkait Kebijakan Kriminal Dalam Ruu KUHP, Sebagai Bahan Bacaan untuk Focus Group Discussion yang diselenggarakan ELSAM dengan tema: "Melihat Politik Kodifikasi dalam Rancangan KUHP", Hotel Ibis Tamarin, Jakarta.

Owens, Eric W.; Behun, Richard J.; Manning,; Jill C. \& Reid, Rory C., (2012). "The Impact of Internet Pornography on Adolescents: A Review of the Research". Sexual Addiction \& Compulsivity, 19, pp. 99-122, DOI: 10.1080/10720162.2012.660431

Santoso, Topo. (2001). Menggagas Hukum Pidana Islam: Penerapan Syariat Islam Dalam Konteks Modernitas, Bandung: Asy Syaamil.

Shidqy, Ni'mat. (1994). Pamer Aurat (At-Tabarruj), Jakarta: Granada Nadia.

Soekamto, Soerjono. (1997). Pokok-pokok Sosiologi Hukum, Jakarta: Raja Grafindo.

Tair, M.A. \& van der Tas, H., (1972). Kamus Belanda: Belanda-Indonesia, Indonesia-Belanda, Djakarta: Timun Mas.

UNFPA. (2014). Reproductive Rights are Human Rights: A Handbook for National Human Rights Institutions.

Yanlua, Mohdar. (2015). "Prospective Islamic Law in Indonesia". Journal of Humanity, Vol. 3, No. 1, pp. 19-21, doi:10.14724/03.02

Ybarra, Michele L. \& Mitchell, Kimberly J., (2005). "Exposure to Internet Pornography among Children and Adolescents: ANational Survey". Cyberpsychology \& Behavior, Volume 8, (5)

Zein, Achyar. (2005). "Prinsip-prinsip Hukum Dalam Al-Qur'an", Sumber: http://www.waspada.co.id/serba_waspada/mimbar_jumat/artikel.php?article_id=65043 
